Cavalcanti, G. A. de O.'; Barreto Filho, J. B.'; Costa, G. M.'; Silva, F. B.'; Mian, G. F.'

\section{9 - Uso da citologia aspirativa do parênquima testicular no diagnóstico de Azoospermia em um cão da raça pastor alemão}

1- Departamento de Medicina Veterinária da Universidade Federal de Lavras (UFLA), Lavras-MG

A azoospermia (ausência de espermatozóides no ejaculado) é de ocorrência relativamente comum na clínica da reprodução em medicina veterinária, podendo ocorrer em diversas espécies domésticas, e já foi descrita em suínos, equinos, bovinos e caninos. Suas causas podem estar relacionadas à produção primária de espermatozóides, como no caso de hipoplasia testicular e espermiogênese imperfeita, e nestas condiçòes a sede da patologia é o parênquima testicular. Em casos de ejaculação retrógrada pode ser observada oligozoospermia, podendo, em circunstâncias extremas, ocorrer também azoospermia. Outras possíveis causas deste processo são patologias de caráter congênito relacionadas à formação e ao desenvolvimento dos ductos de Wolff, onde pode-se constatar aplasia ou atresia segmentar dos canais epididimários. Problemas de infertilidade adquirida também são identificados e normalmente conseqüentes à processos infecciosos do trato reprodutivo. No diagnóstico de azoospermia é necessário, então, localizar a origem do problema e distinguir até qual linhagem celular a espermatogênese se processa. No exame do parênquima testicular, com a finalidade de se diagnosticar azoospermia, podem ser utilizadas as técnicas de biópsia ou citologia aspirativa. Estas técnicas, apesar de serem de grande utilidade e alcance no diagnóstico, apresentam o inconveniente de serem invasivas e causarem danos a barreira hemato-testicular, podendo levar à produção de anticorpos anti-espermatozóides, causando orquite auto-imune. A citologia aspirativa com agulha fina é menos agressiva e com resultados, na grande maioria das vezes iguais a biópsia, porém é pouco relatada na exploração do parênquima testicular em medicina veterinária. Neste trabalho utilizou-se a técnica de citologia aspirativa com agulha fina de parênquima testicular como exame auxiliar em caso de infertilidade canina masculina. Um cão, azoospérmico, da raça Pastor Alemão, com três anos de idade, pesando $38 \mathrm{Kg}$, sem histórico de coberturas anteriores, não apresentava alteração ao exame físico geral e específico. Foram efetuadas sete coletas de sêmen em dias diferentes, e à microscópica de luz, os ejaculados não apresentaram espermatozóides em seis coletas e a presença de apenas um espermatozóide sem motilidade foi observada na análise de uma coleta. Foi efetuada urinálise antes e após uma das coletas de sêmen onde não foram encontradas evidências de retro-ejaculação. $\mathrm{O}$ teste sorológico em imunodifusão em gel de ágar $\mathrm{e} o$ isolamento em ágar triptose foram negativos para Brucella canis, e o $\mathrm{pH}$ medido por meio de fitas de reagentes Merck ${ }^{\circledR}$ foi de aproximadamente 7,0. Efetuou-se tricotomia, anti-sepsia locais e anestesia dissociativa do animal com o uso de clorpromazina $1 \mathrm{mg} / \mathrm{Kg}$ via endovenosa, e após 10 minutos, administraram-se juntos e por via endovenosa midazolam $0,3 \mathrm{mg} / \mathrm{Kg}$ e quetamina $2 \mathrm{mg} / \mathrm{Kg}$. A citologia aspirativa foi realizada em ambos os testículos, sendo usadas agulhas $25 \times 8 \mathrm{~mm}$ e $25 \times 7 \mathrm{~mm}$ em testículo esquerdo e direito respectivamente. À microscopia, foram observados em ambos os testículos, espermatozóides apresentando gota citoplasmática proximal, indicando que a espermatogênese se processava completamente e possivelmente tratava-se de obstrução de epidídimo ou de ductos deferentes. Após a citologia recomendou-se ao cão repouso de três dias e a utilização de flunixin meglumine $1 \mathrm{mg} / \mathrm{Kg}$ a cada 24 horas, por 3 dias, por via oral, sendo que nenhuma alteração comportamental ou inflamação local foram identificadas pelo proprietário. A citologia aspirativa é um exame de fácil execução, pouco invasivo, com poucos efeitos colaterais e eficaz na avaliaçào de parênquima testicular em casos de azoospermia no cão. 